ПРОБЛЕМА ПІДГОТОВКИ МАЙБУТНІХ ФАХІВЦІВ

ЗАЛІЗНИЧНОГО ТРАНСПОРТУ В ЗАКЛАДАХ ОСВІТИ УКРАЇНИ

У ДИСЕРТАЦІЙНИХ ДОСЛІДЖЕННЯХ

\title{
THE PROBLEM OF RAILWAY TRANSPORT SPECIALISTS TRAINING IN EDUCATIONAL INSTITUTIONS OF UKRAINE IN DISSERTATIONS
}

УдК 378:656.2-051(477.7)

(09)«19/20»(043.3)

DOI https://doi.org/10.32843/2663-

$6085 / 2020 / 30-2.4$

\section{Коваленко О.М.,}

аспірант кафедри педагогіки,

психології й освітнього менеджменту

імені професора Євгена Петухова

Херсонського державного університету
Стаття присвячена вивченню проблеми підготовки фрахівців залізничного транспорту в закладах освіти Украӥни у дисертаційних дослідженнях вітчизняних і зарубіжних авторів. Обгрунтована актуальність проблеми підготовки фрахівців залізничного транспорту в закладах освіти України, яка полягає в тому, що нині відсутнє комплексне та всебічне дослідження, котре б розкривало проблеми підготовки фрахівців залізничного транспорту, що дає змогу використати позитивний історичний досвід у сучасному освітньому процесі. Автор аналізує вітчизняні та зарубіжні дисертаційні дослідження, які $\epsilon$ дотичними до проблеми підготовки фрахівців залізничного транспорту в закладах освіти України. У статті зазначається, що окремі аспекти проблеми підготовки фрахівців залізничного транспорту в закладах освіти України відображені у дисертаціях М. Гончара, О. Данилової, Л. Зельман, В. Ларіна, І. Лікарчука, Є. Масуфрранової, О. Микитенко, А. Нєстєрова, Р. Пономаренко, І. Федосової, Т. Шаргун. Проаналізувавши історико-педагогічні роботи, автор доходить висновку, що не існує комплексних і всебічних досліджень, які би повною мірою висвітлювали проблему підготовки майбутніх фрахівців залізничного транспорту в навчальних закладах України другої половини XIX - початку XXI cm. Науковці вивчали систему професійно-технічної або вищої освіти загалом, не виокремлюючи з неї підготовку фрахівців залізничного транспорту (О. Данилова, Л. Зельман, І. Лікарчук, О. Микитенко, А. Нєстєров, І. Федосова), або приділили увагу підготовці майбутніх фрахівців залізничного транспорту в чітко окреслені часові періоди, які не збігаються або частково збігаються з обраними нами хронологічними межами (М. Гончар, В. Ларін, Є. Масусрранова, Т. Шаргун).

Ключові слова: підготовка залізничників, заклади освіти України, дисертаційні дослідження, срахівці залізничного транспорту.
The article deals with the research of the problem of railway transport specialists training in educational institutions of Ukraine in national and foreign dissertations. The author explains the relevance of the study of the problem of railway transport specialists training in educational institutions of Ukraine, pointing out that currently there is no comprehensive study that would reveal the problems of railway transport specialists training, which allows using positive historical experience in the modern educational process. The author analyses national and foreign dissertations, which are related to the problem of railway transport specialists training in educational institutions of Ukraine. The article notes that some aspects of the problem of railway transport specialists training in educational institutions of Ukraine are reflected in some national and foreign dissertations by $M$. Honchar, O. Danylova, L. Zelman, V. Larin, I. Likarchuk, E. Masufranova, O. Mykytenko, A. Nesterova, R. Ponomarenko, I. Fedosova, T. Sharhun. Analysing the historical and pedagogical works, the author concludes that currently there are no comprehensive studies that fully cover the problem of future railway transport specialists training in educational institutions of Ukraine in the second half of the XIX early XXI century. Scientists only investigated the system of vocational or higher education in general, without separating the railway transport specialists training problem (O. Danylova, L. Zelman, I. Likarchuk, O. Mykytenko, A. Nesterov, I. Fedosova) or paid attention to the preparation of railway transport specialists in clearly defined time periods that do not coincide or partially coincide with our chosen chronological boundaries of the study (M. Gonchar, V. Larin, E. Masufranova, T. Sharhun).

Key words: training of railway employees, educational institutions of Ukraine, dissertations, specialists of railway transport.
Постановка проблеми в загальному вигляді. Питання підготовки майбутніх фрахівців залізничного транспорту $€$ актуальним на сучасному етапі розвитку системи освіти України. Система підготовки майбутніх фахівців залізничного транспорту перебуває у процесі розвитку і трансорормацій. Зміст, методи, форми та засоби навчання фрахівців-залізничників $є$ об'єктом дослідження багатьох науковців, однак вітчизняна історіограсрія не містить праць, які би повно та всебічно розкривали питання підготовки майбутніх фрахівців залізничного транспорту.

Аналіз останніх досліджень і публікацій. Окремі аспекти проблеми підготовки фрахівців залізничного транспорту в закладах освіти України висвітлені у вітчизняних і зарубіжних дисертаційних дослідженнях М. Гончара, О. Данилової, Л. Зельман, В. Ларіна, І. Лікарчука, Є. Масуфрранової, О. Микитенко, А. Нєстєрової, Р. Пономаренко, І. Федосової, Т. Шаргун.

Виділення не вирішених раніше частин загальної проблеми. Насамперед маємо констатувати, що серед дисертацій бракує праць, які детально та всебічно розкривають питання підготовки майбутніх фрахівців залізничного транспорту у досліджуваний нами період, що дозволило б виокремити певний історико-педагогічний досвід та окреслити провідні тенденції в системі підготовки 
відповідних фрахівців [4, с. 252]. Дисертації М. Гончара «Розвиток нижчої професійної освіти на Півдні України у II половині XIX - початку XX століття» (2015) [1], О. Данилової «Розвиток професійнотехнічної освіти на Півдні України (1958-1998рр.)» (2015) [2], Л. Зельман «Підготовка кваліфікованих робітників сорери обслуговування у професійнотехнічних навчальних закладах України (1969 р. початок XXI століття)» (2017) [3], В. Ларіна «Підготовка срахівців середньої ланки та кваліфікованих робітників для залізничного транспорту Росії в кінці XIX-XX ст.» (1998р.) [5], І. Лікарчука «Управління системами підготовки квалісрікованих робітників в Україні: педагогічний аспект (1888-1998 роки)» (1999) [6], Є. Масуфрранової «Розвиток соціальної сфрери вітчизняного залізничного транспорту в 1945-1965 рр. (на матеріалах Курської області)» (2016) [7], О. Микитенко «Становлення і розвиток підготовки кваліфрікованих робітників для легкої промисловості у технічних училищах України (1954-1984 рр.)» (2016) [8], А. Нєстєрова «Історія професійно-технічної освіти в Ставропіллі та Кубані» (2006) [9], І. Федосової «Розвиток вищої інженерно-технічної освіти в Україні (кінець XIX 30-ті роки XX століття)» (2014) [10], Т. Шаргун «Розвиток теоретичних та методичних засад підготовки майбутніх фрахівців залізничного транспорту в Україні (XIX - початок XX століття)» (2018) [11] є дотичними до теми нашого дослідження.

Метою статті $€$ аналіз джерельної бази проблеми підготовки майбутніх фахівців залізничного транспорту в навчальних закладах України другої половини XIX - початку XXI ст. на прикладі дисертаційних досліджень вітчизняних і зарубіжних учених.

Виклад основного матеріалу. Деякі науковці присвятили свої пошуки системам профресійнотехнічної або вищої освіти загалом.

Так, дисертація І. Лікарчука присвячена історії розвитку управління системами підготовки робітничих кадрів в Україні у 1888-1998 рр. Науковець проаналізував конкретно-історичні обставини, дослідив систему підготовки робітничих кадрів як педагогічну систему з виробничими срункціями та здійснив класифрікацію типів закладів освіти. I. Лікарчук визначив систему підготовки робітничих кадрів як сукупність освітніх програм і державних освітніх стандартів для підготовки кваліфікованих робітників будь-якої галузі $[4$, с. 251] і не тільки обґрунтував періодизацію історії підготовки робітничих кадрів і класифрікував основні типи закладів нижчої профресійної освіти, у яких здійснювалася підготовка робітничих кадрів, а й виділив основні тенденції та чинники підготовки робітничих кадрів у зазначений історичний період. Особливий інтерес для нашого дослідження становлять п'ятий і шостий розділ, у яких дослідник аналізує систему професійно-технічної освіти з 1946 по 1998 рр. [6].
І. Федосова вперше розкрила теоретико-практичні засади розвитку вищої інженерно-технічної освіти України наприкінці XIX - у 30-ті рр. XX ст. та визначила передумови їі становлення. Проаналізувавши провідні тенденції розвитку вищої інженерно-технічної освіти, дослідниця виокремила значущі, на її думку, періоди: 80-ті рр. XIX ст. 1916 р., 1917-1929 рр., 1930-1939 рр., відповідно до яких здійснює порівняльний історико-педагогічний аналіз змісту, фрорм і методів розвитку вищої інженерно-технічної освіти в Україні наприкінці XIX - 30-ті рр. XX ст. [4, с. 251].

О. Данилова у своєму дослідженні «Розвиток профеесійно-технічної освіти на Півдні України (1958-1998 рр.)» розкриває особливості розвитку професійно-технічної освіти південного регіону України у 1958-1998рр., обґрунтовує періодизацію історії розвитку професійно-технічної освіти на Півдні України цього періоду та визначає провідні тенденції. Зокрема, О. Данилова виділяє такі етапи розвитку: I період (1958-1968 рр.) - період становлення; II (1969-1987 рр.) - період інтенсифрікації; III (1988-1998рр.) - період суперечливості розвитку. У другому розділі «Професійно-технічна освіта на Півдні України у другій половині XX століття» дослідниця аналізує становлення та інтенсисрікацію розвитку системи профресійно-технічної освіти з 1958 по 1998 рр. Серед типів професійнотехнічних навчальних закладів виділяє і залізничні училища, однак аналізує їх не окремо, а лише як один із типів навчальних закладів у системі профресійно-технічної освіти [2].

Незважаючи на те, що робота А. Нєстєрова висвітлює історію профресійно-технічної освіти на Ставропіллі та Кубані, вона містить інформацію щодо розвитку системи профеесійно-технічної освіти СРСР у 1940-1980 рр., до складу якого входила й Україна [4, с. 251]. Крім того, в дисертації подано досить потужний історіографрічний опис літературних джерел радянського періоду, який становить значний інтерес для нашого дослідження [9].

Ще більший інтерес викликають дисертації Л. Зельман та О. Микитенко. Л. Зельман у роботі «Підготовка квалісрікованих робітників сфери обслуговування у професійно-технічних навчальних закладах України (1969 р. - початок XXI століття)» виявила тенденції розвитку майбутніх кваліфікованих робітників ссрери обслуговування у професійно-технічних закладах освіти України з 1969 р. до початку XXI ст. Також дослідниця уточнила та доповнила періодизацію розвитку професійної підготовки майбутніх кваліфікованих робітників [3].

Наукова праця О. Микитенко присвячена становленню і розвитку підготовки кваліфікованих робітників для легкої промисловості у технічних училищах України в 1954-1984рр. Дослідниця 
вперше розробила періодизацію історії розвитку профресійної підготовки майбутніх кваліфікованих робітників на базі повної загальної середньої освіти у технічних училищах України в 1954-1984 рр., а також у першому розділі схарактеризувала особливості профеесійної підготовки майбутніх кваліфрікованих робітників у технічних училищах [4, с. 252]. У цьому розділі містяться й загальні відомості про залізничні навчальні заклади.

Більш-менш детальну інформацію про підготовку майбутніх фрахівців залізничного транспорту містять дисертації М. Гончара, В. Ларіна, $€$. Масуфрранової, Т. Шаргун.

Наприклад, М. Гончар комплексно дослідив вітчизняний досвід підготовки кваліфікованих робітників у нижчих професійних навчальних закладах Півдня України у II половині XIX - на початку XX ст., обґрунтував періодизацію розвитку системи нижчої професійної освіти на Півдні України у визначених хронологічних межах і виокремив три періоди: становлення (1851-1871рр.), інтенсифрікації (1872-1901рр.) та модернізації (1902-1920 рр.). У процесі дослідження М. Гончар дослідив зміст, фрорми, методи та засоби навчання і виховання, виділив такі форми навчання, як практичне навчання у майстернях, у господарствах, проходження практики на виробництві. На думку автора, використовувалися такі методи, як розповідь, пояснення, бесіда, заучування, метод прикладу, ілюстрування та демонстрування, вправи за умов, наближених до виробничих, написання ресрератів і звітів про проведені роботи й екскурciї [4, с. 252]. М. Гончар схарактеризував основні риси розвитку системи закладів нижчої профресійної освіти на Півдні України зазначеного історичного періоду (залучення урядових, громадських організацій і приватних осіб до організації підготовки квалісікованих робітничих кадрів; створення специфрічних типів професійних навчальних закладів; домінування підготовки кваліфікованих кадрів із судноводіння, садівництва, ремісництва тощо), а також систематизував мережу закладів нижчої профресійної освіти на Півдні України за спрямуванням (сільськогосподарським, комерційним, транспортним, промисловим) [1].

Дисертаційне дослідження Т. Шаргун «Розвиток теоретичних та методичних засад підготовки майбутніх фахівців залізничного транспорту в Україні (XIX - початок XX століття)» вивчає розвиток підготовки майбутніх фахівців залізничного транспорту в Наддніпрянській Україні, а також на західноукраїнських землях за часів Австрійської, Австро-Угорської імперії та Другої Речі Посполитої, охоплюючи період із першої половини XIX ст. до 1939 р. Дослідниця розробила періодизацію розвитку підготовки майбутніх фрахівців залізничного транспорту XIX - початку XX ст. та виявила тенденції та еволюцію педагогічних систем і кон- цепцій освіти XIX - початку XX ст. в контексті підготовки майбутніх фрахівців залізничного транспорту [11].

В. Ларін розкриває сутність становлення і розвитку системи підготовки кадрів середньої ланки та кваліфікованих робітників для залізничного транспорту Росії кінця XIX - XX ст., проводить аналіз організації та змісту навчально-виховної роботи в залізничних професійних закладах освіти в історико-педагогічному аспекті, що дає більш повну картину історії вітчизняної підготовки фрахівців середньої ланки та кваліфікованих робітників. Науковець виявив специсріку співвідношення змісту та технологій загальної, загальнотехнічної, спеціальної освіти в навчальновиховному процесі підготовки фрахівців середньої ланки та кваліфрікованих робітників залізничного транспорту [4, с. 252]. Особливий інтерес для нас становить другий розділ дисертації, який охоплює період 1917-1991 рр. У цьому розділі дослідник аналізує зміст, срорми та методи підготовки кадрів середньої ланки і квалісрікованих робітників для залізничного транспорту Росії та доходить висновків, що між науково-технічним розвитком транспорту і системою професійно-технічної освіти простежується досить складний взаємозв'язок, зумовлений становленням і розвитком закладів освіти шляхів сполучення різного типу, потребами виробництва, змінами змісту і характеру праці працівників, викликаними впровадженням на транспорті досягнень науково-технічного прогресу. Вдосконалення змісту освіти й організації процесу навчання в залізничних навчальних закладах повинні були не тільки відповідати сучасним вимогам, а й випереджати їх, працювати на перспективу соціально-економічного та науково-технічного розвитку галузі [5].

Робота $€$. Масудрранової «Розвиток соціальної сорери вітчизняного залізничного транспорту в 1945-1965 рр. (на матеріалах Курської області)» (2016) присвячена характеристиці основних напрямів державної та відомчої політики розвитку соціальної сфери на залізничному транспорті, а також вивченню регіональних особливостей і джерел кадрового поповнення, динаміці підготовки кадрів на залізничних підприємствах регіону. Дослідниця дає об'єктивну оцінку процесам професійної підготовки в системі вищої, середньої спеціальної освіти залізничного транспорту у зазначений історичний період. У розділі II дисертації «Реалізація державної програми підготовки кадрів для залізничного транспорту в середині 1940-х - на початку 1960-х років» проаналізовано підготовку кваліфікованих фрахівців у вищих і середніх спеціальних навчальних закладах і технічне навчання молоді в залізничних училищах Курської області, а також виробнича підготовка та виховання залізничних кадрів 
в 1940-х - на початку 1960-х рр. Незважаючи на той фракт, що вчена аналізує тільки залізничні училища Курської області, нормативно-правова база її дослідження стосується всіх навчальних закладів зазначеного профрілю на території сучасної України [7]

Висновки. Проаналізувавши історико-педагогічні роботи, можна зробити висновок, що нині немає комплексних і всебічних досліджень, які би повною мірою висвітлювали проблему підготовки майбутніх фрахівців залізничного транспорту в навчальних закладах України другої половини XIX - початку XXI ст. Науковці вивчали систему профресійно-технічної або вищої освіти загалом, не виокремлюючи 3 неї підготовку фахівців залізничного транспорту (О. Данилова, Л. Зельман, І. Лікарчук, О. Микитенко, А. Нєстєров, І. Федосова), або приділили увагу підготовці майбутніх фрахівців залізничного транспорту в чітко окреслені часові періоди, які не збігаються або частково збігаються з обраними нами хронологічними межами (М. Гончар, В. Ларін, Є. Масуфранова, Т. Шаргун).

3 огляду на зазначене вище вважаємо доцільним подальше вивчення джерельної бази проблеми підготовки майбутніх фахівців залізничного транспорту в навчальних закладах України другої половин XIX - початку XXI ст., зокрема шляхом аналізу монографрічних досліджень, архівних матеріалів, періодичних видань тощо.

\section{БІБЛІОГРАФІЧНИЙ СПИСОК:}

1. Гончар М.В. Розвиток нижчої професійної освіти на Півдні України у II половині XIX - початку XX століття : дис. ... канд. пед. наук : 13.00.01 / Комунальний вищий навчальний заклад «Херсонська академія неперервної освіти». Херсон, 2015. 301 с.

2. Данилова О.І. Розвиток профеесійно-технічної освіти на Півдні України (1958-1998рр.) : дис. ... канд. пед. наук : 13.00.01 / Терноп. нац. пед. ун-т ім. В. Гнатюка. Тернопіль, 2015. 216 с.

3. Зельман Л.Н. Підготовка кваліфікованих робітників сорери обслуговування у професійно-технічних навчальних закладах України (1969 р. - початок XXI століття) : дис. ... канд. пед. наук : 13.00.04 / Інститут просресійно-технічної освіти НАПН України,
Київ, Львівський державний університет безпеки життєдіяльності ДСНС України, Львів, 2017. 278 с.

4. Коваленко О.М. Відображення проблеми підготовки майбутніх фрахівців залізничного транспорту в дисертаційних дослідженнях. Współczesne trendy rozwoju edukacji $i$ nauki $w$ kontekście interdyscyplinarnym : Materiały III Międzynarodowej Konferencji Naukowo-Praktycznej, 29-30 marca 2018 roku. Częstochowa - Użhorod - Drohobycz: Posvit, 2018. C. 250-252.

5. Ларин В.К. Подготовка специалистов среднего звена и квалисрицированных рабочих для железнодорожного транспорта России в конце XIX-XX вВ. автореф. дис. ... канд. пед. наук : 13.00.01 / Курский государсвенный педагогический университет. Курск, 1998. 37 с

6. Лікарчук І.Л. Управління системами підготовки кваліфікованих робітників в Україні: педагогічний аспект (1888-1998 роки)» : автореф. дис. ... докт. пед. наук : 13.00.04 / Інститут педагогіки і психології профресійної освіти АПН України. Київ, 1999. 38 с.

7. Масуфранова Е.А. Развитие социальной сореры отечественного железнодорожного транспорта в 1945-1965 гг. (по материалам Курской области) : дис. ... канд. истор. наук : 07.00.02 / ЮгоЗападный государственный университет. Тамбов, 2016. 310 c.

8. Микитенко О.С. Становлення і розвиток підготовки кваліфрікованих робітників для легкої промисловості у технічних училищах України (1954-1984рр.) : дис. ... канд. пед. наук : 13.00.04 / Інститут педагогічної освіти і освіти дорослих НАПН України. Київ, 2016. 296 c.

9. Нестеров А.С. История профрессионально-технического образования на Ставрополье и Кубани : автореф. дис. ... канд. пед. наук : 07.00.02 / Ставропольский государственный университет. Ставрополь, 2006. 28 c.

10. Федосова І.В. «Розвиток вищої інженерно-технічної освіти в Україні (кінець XIX - 30-ті роки XX століття)» : автореф дис. ... докт. пед. наук : 13.00.01 / Уманський державний педагогічний університет імені Павла Тичини. Умань, 2014. 40 с.

11. Шаргун Т.О. Розвиток теоретичних та методичних засад підготовки майбутніх фрахівців залізничного транспорту в Україні (XIX - початок XX століття) : дис. ... докт. пед. наук : 13.00.01 / Хмельниц. гуманітар.-пед. акад. Хмельницький, 2018. 625 с. 